\title{
Nitric oxide donating compounds stimulate human colonic ion transport in vitro
}

\author{
W A Stack, B Filipowicz, C J Hawkey
}

\begin{abstract}
Background-Nitric oxide (NO) has been recently implicated as a possible mediator of bowel inflammation and has also been shown to stimulate electrogenic chloride secretion in rat and guinea pig intestine. This study therefore investigated the effect on two NO donors, sodium nitroprusside (SNP) and S-nitroso- $\boldsymbol{N}$-acetylpenicillamine (SNAP) on human colonic ion transport.
\end{abstract}

Methods-Changes in short circuit current ( $\triangle$ SCC) in response to nitric oxide donating compounds were measured in muscle stripped normal human colon mounted in Ussing chambers. The ion species and intracellular mechanisms responsible for $\triangle$ SCC evoked by SNP were investigated.

Results-Basolateral SNP caused a progressive rise in $\triangle S C C$ over the range $10^{-7}$ to $10^{-4} \mathrm{M}\left(\mathrm{ED}_{50}=2.5 \times 10^{-5} \mathrm{M}\right)$. SNAP $10^{-4} \mathrm{M}$ also evoked a qualitatively similar $\triangle$ SCC compared with SNP $10^{-4} \mathrm{M}$. Basolateral SNP evoked a greater $\triangle S C C$ than apical and this was significantly attenuated by bumetanide $10^{-4} \mathrm{M}(52 \cdot 9 \pm 10 \cdot 1 \%)$ and in chloride free media $(68 \cdot 3 \pm 7 \cdot 3 \%)$. $\Delta$ SCC response to SNP was not significantly changed by basolateral 4-acetamido-4'isothio-cyano-2,2'disulphonic acid stillbene (SITS $10^{-3} \mathrm{M}$ ) an inhibitor of sodium/bicarbonate exchange, or apical amiloride $10^{-5} \mathrm{M}$ an inhibitor of sodium absorption. SNP induced $\triangle$ SCC was also significantly reduced by piroxicam (mean (SEM)) $10^{-5} \mathrm{M}$ (57.9 (11.9)\%), nordihydroguaretic acid $10^{-4} M(48 \cdot 0 \quad(12 \cdot 9) \%)$, tetrodotoxin (TTX $10^{-6} \mathrm{M}, 52 \cdot 3(9 \cdot 1) \%$ ), and practically abolished by TTX and piroxicam together $(96 \cdot 8(3 \cdot 3) \%)$.

Conclusion-NO donors stimulate human colonic ion transport in vitro. For SNP, increased $\triangle S C C$ is at least due in part to chloride secretion, and the response seems to be transduced through enteric nerves and by local prostanoid synthesis. This study provides evidence that NO may be another important mediator of ion transport in human colon.

(Gut 1996; 39: 93-99)

Keywords: nitric oxide, colon, ion transport.

Nitric oxide (NO) was originally described as endothelial derived relaxing factor ${ }^{1}$ and in recent years has been established to be an important biological mediator in a number of tissue functions. ${ }^{2} \mathrm{NO}$ is generated from L-arginine by NO synthase (NOS), which exists as a constitutive (calcium dependent unaffected by glucocorticoids) or inducible (calcium independent, induction inhibited by glucocorticoids) enzyme in many tissue types. ${ }^{2}{ }^{3}$ In recent years NO has also been implicated in regulating an increasing number of physiological and pathophysiological activities in the gastrointestinal tract. ${ }^{4}$ Among its activities in the gastrointestinal tract, NO has been shown to be an inhibitory non-cholinergic non-adrenergic neurotransmitter of intestinal and biliary tract motility ${ }^{5-7}$ and a regulator of mucosal permeability. ${ }^{8}$

It is also becoming apparent that in addition to regulating gastrointestinal motility and permeability, NO may also be an important mediator of intestinal ion transport. Recent animal experiments have shown that NO applied directly, ${ }^{9}$ or via NO donating compounds $^{9-11}$ to experimental animal intestine in vitro, stimulates electrogenic chloride secretion, a mechanism responsible for secretory diarrhoea. ${ }^{12}$ Furthermore, the NO synthase inhibitor $\mathrm{N}^{\mathrm{G}}$-nitro-L-arginine methyl ester (L-NAME) attenuates castor oil ${ }^{13}$ and laxative induced $^{14}$ diarrhoea in rats in vivo. Recently, inducible nitric oxide synthase (iNOS) has been shown to be increased in animal models of experimental colitis ${ }^{15}$ and in active idiopathic ulcerative colitis in humans, ${ }^{16} 17$ suggesting a role for NO in the pathogenesis of these conditions. NO is generated by a number of immunological cell types including mast cells, ${ }^{18}$ neutrophils, ${ }^{19}$ and macrophages ${ }^{20}$ all of which have been shown to be present in increased quantities in the lamina propria and the lumen of inflamed bowel.

It is increasingly recognised that species variation is a feature of intestinal secretion in response to secretagogues. One of us has previously demonstrated species variability in response to histamine stimulation of human colonic ion transport in vitro. ${ }^{21}$ In addition, it has also been recently demonstrated that Clostridium difficile toxin B may be more important in the pathogenesis of pseudomembranous colitis than toxin $\mathrm{A}$ in human colon, which differs from data in experimental animals. ${ }^{22}$ For these reasons we have used normal colonic mucosa mounted in Ussing chambers to investigate ion transport responses to $\mathrm{NO}$ donating compounds and to identify possible mechanisms by which this action occurs.

\section{Methods}

Specimens and tissue preparation

Tissues were obtained from patients undergoing colonic resection for carcinoma $(n=40)$ 
or diverticular disease $(n=3)$. Left sided specimens $(n=34)$ were taken from the descending or sigmoid colon and right sided specimens $(n=9)$ from the caecum and ascending colon. All tissues were macroscopically normal and at least $4 \mathrm{~cm}$ away from the edge of the tumour or diseased area. In all cases, the resection margins adjacent to where the tissues were taken from, were confirmed to be histologically normal. Specimens were transferred immediately in Krebs-Henseleit solution (composition; $\mathrm{NaCl} 118 \mathrm{mmol} / \mathrm{h}, \mathrm{KCl} 4.7 \mathrm{mmol} / 1$, $\mathrm{CaCl}_{2} \quad 2.5 \mathrm{mmol} / \mathrm{l}, \mathrm{MgSO}_{4} \quad 1.2 \mathrm{mmol} / \mathrm{l}$, $\mathrm{KH}_{2} \mathrm{PO} 41.2 \mathrm{mmol} / \mathrm{l}, \mathrm{NaHCO}_{3} 25 \mathrm{mmol} / \mathrm{l}$, and d-glucose $11.1 \mathrm{mmol} / \mathrm{l}$ ) at $4^{\circ} \mathrm{C}$ to the laboratory. Mucosal sheets were stripped of their underlying smooth muscle by blunt dissection and mounted in Ussing chambers. The time from resection to tissues being mounted in Ussing chambers was approximately 20 minutes. In some experiments, the chloride containing salts of the Krebs-Henseleit solution were replaced with sodium gluconate 117 $\mathrm{mmol} / \mathrm{h}$, potassium gluconate $4.7 \mathrm{mmol} / \mathrm{l}$, and calcium sulphate dehydrate $2.5 \mathrm{mmol} / \mathrm{l}$. The study was approved by the ethics committee of the University Hospital, Queens Medical Centre, Nottingham.

\section{Ussing chamber studies}

Four sheets of mucosa obtained from each patient were mounted simultaneously in Ussing chambers (window area $1.13 \mathrm{~cm}^{2}$ ) and bathed on either side with $10 \mathrm{ml}$ of Krebs-Henseleit solution. Tissues were maintained at $37^{\circ} \mathrm{C}$, gassed with $95 \% \mathrm{O}_{2} / 5 \% \mathrm{CO}_{2}$ using an air lift system. The bathing solutions were connected via agar bridges $(3 \mathrm{MKCl}$ in $3 \%$ agar) to calomel electrodes to measure the potential difference between the two tissues. Tissues were voltage clamped to zero potential difference using a DVC-1000 automatic voltage clamp (World Precision Instruments, New Haven, CT) with $\mathrm{Ag}-\mathrm{AgCl}$ electrodes connected to the agar bridges. Short circuit current (SCC) was continually monitored using an MP 100 data acquisition system (Biopac Systems) linked to the voltage clamp. The preparation was unclamped every five minutes to measure open circuit voltage and changes in resistance were derived from voltage and $\triangle$ SCC using Ohm's law.

Tissues were allowed to establish a stable SCC for at least 45 minutes prior to any drug addition. Drugs were added to solutions bathing either the serosal (basolateral) or the mucosal (apical) side of the chamber 15 minutes prior to SNP or SNAP. Changes in short circuit current $(\triangle S C C)$ were determined from the difference between basal and maximum SCC deflection after a drug was administered. At the end of each experiment the cholinomimetic agent carbachol $\left(10^{-4} \mathrm{M}\right)$ was applied to the basolateral side of the preparation to confirm tissue viability. Results $(\Delta S C C)$ are expressed in $\mu \mathrm{A} / \mathrm{cm}^{2}$. All data are presented as mean (SEM) and statistically significant differences between mean values were assessed by means of Student's $t$ test for paired or unpaired samples as appropriate. Drugs were added basolaterally unless otherwise stated.

\section{Materials}

Sodium nitroprusside, piroxicam, bumetanide, carbachol, amiloride, nordihydroguaiaretic acid (NDGA), and $\mathrm{N}^{\mathrm{G}}$-nitro-L-arginine methyl ester (L-NAME) were obtained from Sigma Chemical, Poole, Dorset, UK. Snitroso- $N$-acetyl-penicillamine (SNAP) and 4-acetamido-4' -isothio-cyano-2,2' disulphonic acid stillbene (SITS) were obtained from Calbiochem-Novabiochem, La Jolla, CA.

\section{Results}

\section{Basal parameters}

In all, 145 separate colonic specimens from 43 patients (34 left sided, and nine right sided) were included for analysis of baseline parameters and responses to NO donating drugs. Table I shows basal SCC, resistance and conductance as well as responses to basolateral carbachol $10^{-4} \mathrm{M}$. Although basal SCC and voltage appeared somewhat lower in left compared with right colon this did not reach statistical significance (Table I). Tissue conductance and the response to carbachol $10^{-4} \mathrm{M}$ was similar in right and left sided specimens used in these studies. A pharmacological approach was used to identify charge carrying ions and possible mechanisms of action of NO donors. Piroxicam $10^{-5} \mathrm{M}$, tetrodotoxin $10^{-6} \mathrm{M}$, and amiloride $10^{-4} \mathrm{M}$ significantly reduced basal SCC and SITS $10^{-3} \mathrm{M}$ significantly increased basal SCC but none of these drugs when administered alone significantly changed $\triangle$ SCC response to carbachol compared with controls $\left(10^{-4} \mathrm{M}\right.$ Table II).

\section{SCC responses in human colon to stimulation} with NO donors

SNP evoked a concentration dependent increased $\triangle$ SCC from $10^{-7}$ to $10^{-4} \mathrm{M}$ $\left(E_{50}=2.5 \times 10^{-5} \mathrm{M}\right.$, Fig 1). SNP $10^{-4} \mathrm{M}$ exhibited significantly reduced responses to a second application at a similar concentration after 30 minutes; first addition 29.7 (11.9) $\mu \mathrm{A} / \mathrm{cm}^{2}$, second addition $-2 \cdot 8(0 \cdot 7) \mu \mathrm{A} / \mathrm{cm}^{2}$ $(p<0.05, n=7)$. Therefore to avoid problems of tachyphylaxis when constructing a concentration response curve, each piece of data was

TABLE I Basal parameters for right and left colons

\begin{tabular}{llll}
\hline & $\begin{array}{l}\text { Right colon } \\
(n=9 / 34)\end{array}$ & $\begin{array}{l}\text { Left colon } \\
(n=34 / 113)\end{array}$ & $p$ Value \\
\hline Basal SCC $\left(\mu \mathrm{A} / \mathrm{cm}^{2}\right)$ & $97 \cdot 2(11 \cdot 9)$ & $71 \cdot 1(11 \cdot 1)$ & $0 \cdot 26$ \\
Voltage $(\mathrm{mV})$ & $10 \cdot 2(1 \cdot 6)$ & $7 \cdot 6(1 \cdot 2)$ & $0 \cdot 14$ \\
$\begin{array}{l}\text { Conductance }\left(\mathrm{mS} / \mathrm{cm}^{2}\right) \\
\text { Response to carbachol } \\
10^{-4} \mathrm{M}\left(\Delta \mathrm{SCC} \mu \mathrm{A} / \mathrm{cm}^{2}\right)\end{array}$ & $74 \cdot 1(13 \cdot 5)$ & $11 \cdot 4(1 \cdot 2)$ & $0 \cdot 74$ \\
\hline
\end{tabular}

Data are expressed as mean (SEM), $n=$ number of patients/specimens from each patient. Although basal SCC and voltage values were lower in left compared with right and voltage values were lower in left compared with right colons, this did not attain statistical significance (unpaired $t$ carbachol $\left(10^{-4} \mathrm{M}\right)$ were similar for right and left colons. 
TABLE II Influence of drugs on basal short circuit current and carbachol stimulated changes in short circuit current

\begin{tabular}{|c|c|c|c|c|c|c|c|c|c|}
\hline Stimulus & $\begin{array}{l}\text { Piroxicam } \\
\left(10^{-5} M, n=7\right)\end{array}$ & $\begin{array}{l}T T X \\
\left(10^{-6} M, n=6\right)\end{array}$ & $\begin{array}{l}\text { Piroxicam } \\
10^{-5} M \text { and } \\
T T X\left(10^{-6} M\right. \\
n=6)\end{array}$ & $\begin{array}{l}N D G A \\
\left(10^{-4} M, n=7\right)\end{array}$ & $\begin{array}{l}L-N A M E \\
\left(10^{-3} M, n=7\right)\end{array}$ & $\begin{array}{l}\text { Amiloride } \\
\left(10^{-4} M, n=6\right)\end{array}$ & $\begin{array}{l}\text { Bumetanide } \\
\left(10^{-4} M, n=7\right)\end{array}$ & $\begin{array}{l}\text { SITS } \\
\left(10^{-3} M, n=9\right)\end{array}$ & $\begin{array}{l}\text { Bumetanide } \\
10^{-4} M \text { and } \\
\text { SITS }\left(10^{-3} M\right. \\
n=6)\end{array}$ \\
\hline $\begin{array}{l}\text { None } \\
\text { Drug } \\
\text { Carbachol }\end{array}$ & $\begin{array}{c}5 \cdot 4(2 \cdot 1) \\
-37 \cdot 1(8 \cdot 2)^{\star \star}\end{array}$ & $\begin{array}{c}6 \cdot 9(0 \cdot 6) \\
-28 \cdot 3(7 \cdot 2)^{\star \star}\end{array}$ & $\begin{array}{c}2 \cdot 6(1 \cdot 9) \\
-54 \cdot 0(12 \cdot 7)^{\star \star}\end{array}$ & $\begin{array}{c}1 \cdot 9(1 \cdot 7) \\
-30 \cdot 2(9 \cdot 9)^{\star \star}\end{array}$ & $\begin{array}{l}1 \cdot 9(1 \cdot 7) \\
4 \cdot 2 .(4 \cdot 2)\end{array}$ & $\begin{array}{c}0.8(2 \cdot 9) \\
-46 \cdot 6(16 \cdot 1)^{\star}\end{array}$ & $\begin{array}{l}3.5(2.5) \\
2 \cdot 4(8.0)\end{array}$ & $\begin{array}{c}1 \cdot 0(1 \cdot 1) \\
18 \cdot 0(3 \cdot 5)^{\star \star}\end{array}$ & $\begin{array}{l}1.4(1 \cdot 2) \\
6.5(8 \cdot 2)\end{array}$ \\
\hline $\begin{array}{l}10^{-4} \mathrm{M} \\
\text { Drug }+\end{array}$ & $109 \cdot 2(13 \cdot 0)$ & $109 \cdot 2(13.0)$ & $137 \cdot 4(22 \cdot 7)$ & $75 \cdot 0(22 \cdot 7)$ & $91 \cdot 4(22 \cdot 7)$ & $89.8(20.5)$ & $109 \cdot 4(13 \cdot 1)$ & $103.9(27 \cdot 2)$ & $120 \cdot 0(19 \cdot 6)$ \\
\hline $\begin{array}{l}\text { Carbacho } \\
10^{-4} \mathrm{M}\end{array}$ & $114.9(21.0)$ & $66 \cdot 5(12 \cdot 8)$ & $43.3(8 \cdot 8) \dagger$ & $70 \cdot 6(14 \cdot 8)$ & $114 \cdot 6(9 \cdot 6)$ & $112 \cdot 3(16 \cdot 6)$ & $6 \cdot 7(2 \cdot 8) \ddagger$ & $91 \cdot 1(14 \cdot 1)$ & $17 \cdot 2(5 \cdot 8) \ddagger$ \\
\hline
\end{tabular}

Effects of drugs on basal and carbachol stimulated short circuit current in human colon. All drugs were added basolaterally except amiloride, which was added apically. Cro tissues over the same period $\left({ }^{\star} \mathrm{p}<0.05,{ }^{\star \star} \mathrm{p}<0.01\right)$. At the end of each experiment carbachol $10^{-4} \mathrm{M}$ was added and the maximum $\Delta S C C$ was compared in drug tissues over the same period $\left({ }^{\star} \mathrm{p}<0.05,{ }^{\star \star} \mathrm{p}<0.01\right)$. At the end of each experiment carbachol $10^{-4} \mathrm{M}$ was added and the maximum $\Delta S C \mathrm{C}$.
treated and untreated tissues ( $\mathrm{tp}<0.05, \neq \mathrm{p}<0.01$ ). Comparisons were made using Student's paired $t$ test. Data shown as mean (SEM).

derived from a single stimulation of each tissue by SNP. There was no significant reduction in the response to carbachol after a second shot of SNP; ( $\triangle S C C$ response to carbachol $10^{-4} \mathrm{M}$ after SNP $10^{-4} \mathrm{M}$ was $104 \cdot 6$ (9.4) $\mu \mathrm{A} / \mathrm{cm}^{2}, \mathrm{n}=30$ after a single addition and $93.5(14.3) \mu \mathrm{A} / \mathrm{cm}^{2}, \mathrm{n}=7$; after a second addition, $p=0 \cdot 6)$. An alternative NO donor SNAP $10^{-4} \mathrm{M}$ was added and evoked a similar type of response to SNP $10^{-4} \mathrm{M}$ (Fig 2). For the remainder of the experiments SNP $10^{-4} \mathrm{M}$ was used as this concentration gave the maximum $\Delta$ SCC response.

Sidedness of the response to $S N P$

In paired experiments, SNP $10^{-4} \mathrm{M}$ evoked a $\triangle$ SCC of $65.5(24.9) \mu \mathrm{A} / \mathrm{cm}^{2}$ when added basolaterally, which was significantly greater than the response of $14 \cdot 1$ (2) $\mu \mathrm{A} / \mathrm{cm}^{2}$ observed when SNP $10^{-4} \mathrm{M}$ was added apically $(\mathrm{p}=0.05, \mathrm{n}=6)$.

Ionic basis of the response to SNP

Bumetanide $10^{-4} \mathrm{M}$, an inhibitor of the $\mathrm{Na} / \mathrm{K} / \mathrm{Cl}$ cotransporter necessary for chloride secretion ${ }^{23}$ was added basolaterally 15 minutes prior to SNP. In paired tissues this concentration of bumetanide significantly reduced the $\Delta$ SCC response to SNP by $52.9(10.1) \%$; (from $66.1(16.3)$ to $35.4(14.8) \mu \mathrm{A} / \mathrm{cm}^{2}$,

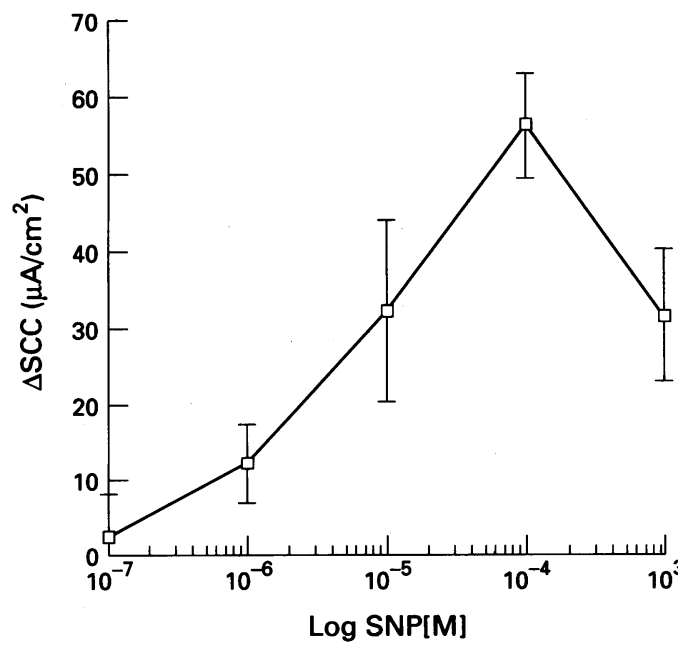

Figure 1: Concentration response curve to basolateral SNP in human colon. SNP evoked a concentration dependen increased $\triangle S C C$ in human colon from $10^{-7}$ to $10^{-4} \mathrm{M}$. Results are mean (SEM) of six patients. Doses were added in separate tissues from the same patients. $\mathrm{p}<0.05 ; \mathrm{n}=7$ ) and practically abolished the response to carbachol $10^{-4} \mathrm{M}$ by $89 \cdot 2(4 \cdot 5) \%$ (from 109.4 (13.0) to $6.7(2.8) \mu \mathrm{A} / \mathrm{cm}^{2}$, $\mathrm{p}<0.01 ; \mathrm{n}=6$ ). Basolateral SITS $10^{-3} \mathrm{M}$ (an inhibitor of sodium/bicarbonate transport in rat colon $^{24}$ and renal proximal tubules ${ }^{25}$ ) did not significantly affect $\triangle S C C$ response to SNP $(\mathrm{p}=0.09, \mathrm{n}=9)$ when added alone, but in combination with bumetanide $10^{-4} \mathrm{M}$ reduced $\triangle$ SCC significantly greater than with bumetanide alone, $(80.0 \quad(6.7) \% \quad v \quad 52.9$ $(10 \cdot 1) \%$ reduction respectively $\mathrm{p}<0.05, \mathrm{n}=7$ Fig 3). Amiloride $10^{-5} \mathrm{M}$, an inhibitor of electrogenic sodium absorption in human colon, ${ }^{26}$ was added apically but did not affect the response to basolateral SNP $10^{-4} \mathrm{M}$ (SNP
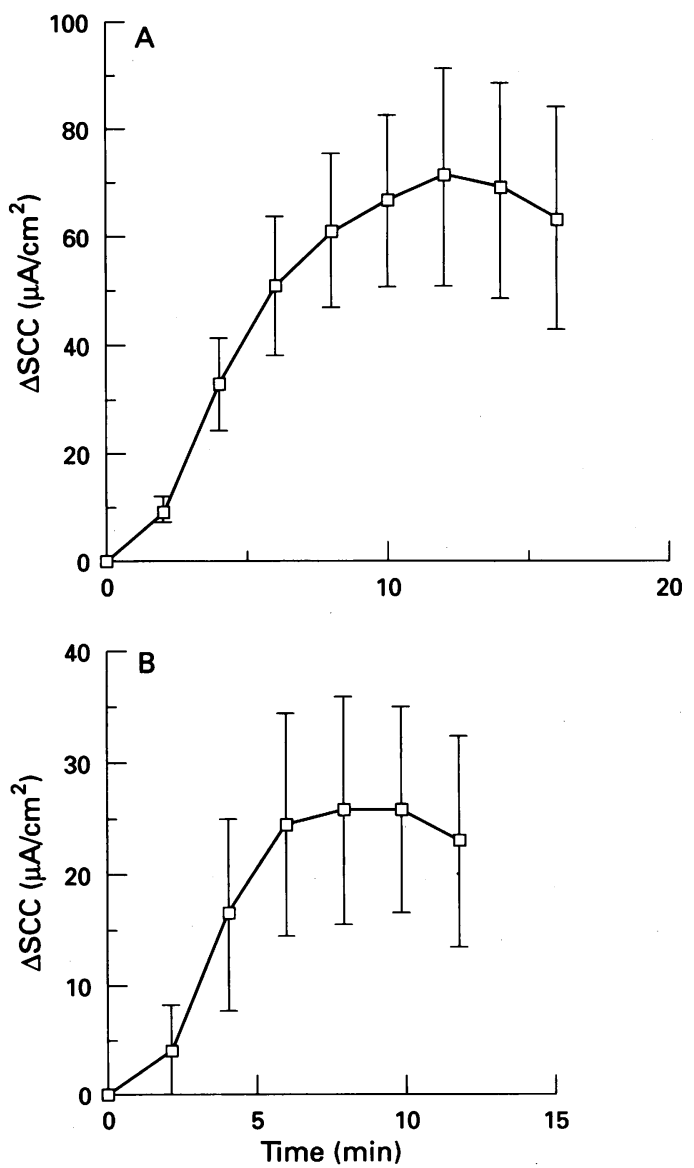

Figure 2: Time course response to $\operatorname{SNP}(A)$ and $S N A P(B)$. Mean $\triangle S C C$ responses to $S N P(n=32)$ and $S N A P(n=8)$ over time. Values for $\triangle S C C$ represent differences in SNP and SNAP stimulated $\triangle S C C$ from the baseline to maximum response in tissues described. Note that both SNP and SNAP evoke qualitatively similar increased $\triangle S C C$ in human colon. 

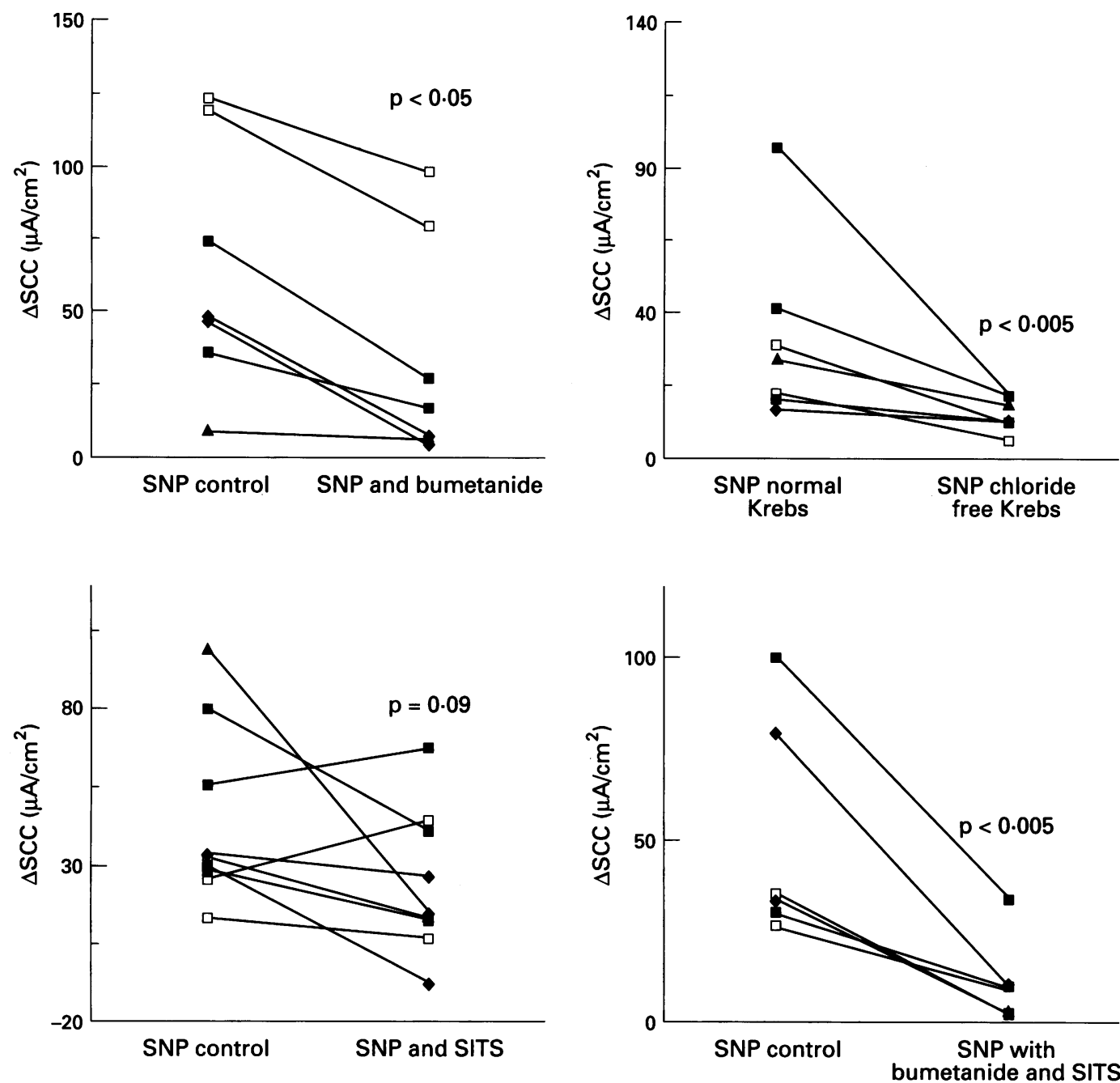

Figure 3: Investigation of the charge carrying ion(s) responsible for $\triangle S C C$ with $S N P$. SNP $\left(10^{-4} M\right)$ was administered to the basolateral side of the tissues 15 minutes after basolateral addition of bumetanide $\left(10^{-4} \mathrm{M}\right)$, SITS $\left(10^{-3} \mathrm{M}\right)$, bumetanide $\left(10^{-4} \mathrm{M}\right)$ and SITS $\left(10^{-3} \mathrm{M}\right)$, and in chloride free media. $\triangle S C C$ values obtained were compared with tissues treated with basolateral $S N P\left(10^{-4} \mathrm{M}\right)$ alone in normal Krebs solution. The effect of SNP was significantly attenuated by bumetanide, bumetanide and SITS, and in chloride free media.

control; $55.9(21.8) \mu \mathrm{A} / \mathrm{cm}^{2} v \mathrm{SNP}$ and amiloride; $\left.59.6(23.8) \mu \mathrm{A} / \mathrm{cm}^{2} ; \mathrm{p}=0.8, \mathrm{n}=6\right)$.

As these inhibitor experiments suggested that electrogenic chloride secretion was the main contributor to SNP induced increased $\triangle S C C$, confirmatory ion substitution studies were performed. In chloride free media, $\triangle$ SCC response to SNP was reduced by $68 \cdot 3(7 \cdot 3) \%$ (from 36.2 (13.6) to $7.0(2.2) \mu \mathrm{A} / \mathrm{cm}^{2} \mathrm{p}<0.05$, $\mathrm{n}=7$; Fig 3) compared with paired tissues bathed in normal Krebs solution. $\triangle S C C$ response to SNP was restored when the chloride free media was replaced with normal Krebs solution (data not shown).

\section{Mechanism of action of SNP}

All antagonists were added basolaterally 15 minutes prior to SNP. Mean peak $\triangle$ SCC responses to SNP $10^{-4} \mathrm{M}$ were reduced by the cyclooxygenase inhibitor piroxicam $10^{-5} \mathrm{M}$ by $57.9(11.9) \%$ (from $75.0(13.4)$ to $29.0(6.9)$ $\left.\mu \mathrm{A} / \mathrm{cm}^{2}, \mathrm{p}<0.05 ; \mathrm{n}=7\right)$. In addition nordihydroguaiaretic acid $10^{-4} \mathrm{M}$, which has both cyclooxygenase and lipoxygenase inhibiting properties, significantly reduced $\triangle$ SCC response to SNP by 48.0 (12.9)\% (from 47.4 $(14 \cdot 6)$ to $\left.21 \cdot 2(7 \cdot 4) \mu \mathrm{A} / \mathrm{cm}^{2}, \mathrm{p}<0 \cdot 05 ; \mathrm{n}=7\right)$.
The neuron blocker tetrodotoxin $10^{-6} \mathrm{M}$ (an inhibitor of fast sodium channels in nerves ${ }^{27}$ ) reduced SNP induced $\triangle$ SCC by $52.3(9 \cdot 1) \%$ (from $75.0(13.4)$ to $29.0(6.9) \mu \mathrm{A} / \mathrm{cm}^{2}$, $\mathrm{p}<0.05 ; \mathrm{n}=6$ ) and the combination of TTX $10^{-6} \mathrm{M}$ and piroxicam $10^{-5} \mathrm{M}$ virtually abolished $\triangle$ SCC with SNP $10^{-4} \mathrm{M}(96.8$ (3.3) $\%$ reduction, $p<0.001, n=6$; Fig 4$)$. The $\Delta$ SCC response to carbachol $10^{-4} \mathrm{M}$ was not affected by piroxicam, TTX, or NDGA at the concentrations used but was significantly reduced by the combination of piroxicam $10^{-5} \mathrm{M}$ and TTX $10^{-6} \mathrm{M}$ together (Table II). The iNOS inhibitor L-NAME $10^{-4} \mathrm{M}$ did not change $\triangle$ SCC response to SNP $10^{-4} \mathrm{M}$ (SNP alone $56.7(22.0) \mu \mathrm{A} / \mathrm{cm}^{2}$, SNP and L-NAME $\left.52 \cdot 6(12 \cdot 7) \mu \mathrm{A} / \mathrm{cm}^{2}, \mathrm{p}=0 \cdot 8 ; \mathrm{n}=7\right)$.

\section{Discussion}

There is increasing evidence that NO may control many important functions of the gastrointestinal tract ${ }^{4}$ and another role that has been recently recognised is its ability to regulate intestinal ion transport in animals. ${ }^{9-11}$ However the role of NO in regulating human colonic ion transport has not previously been evaluated. Using two different NO donating 

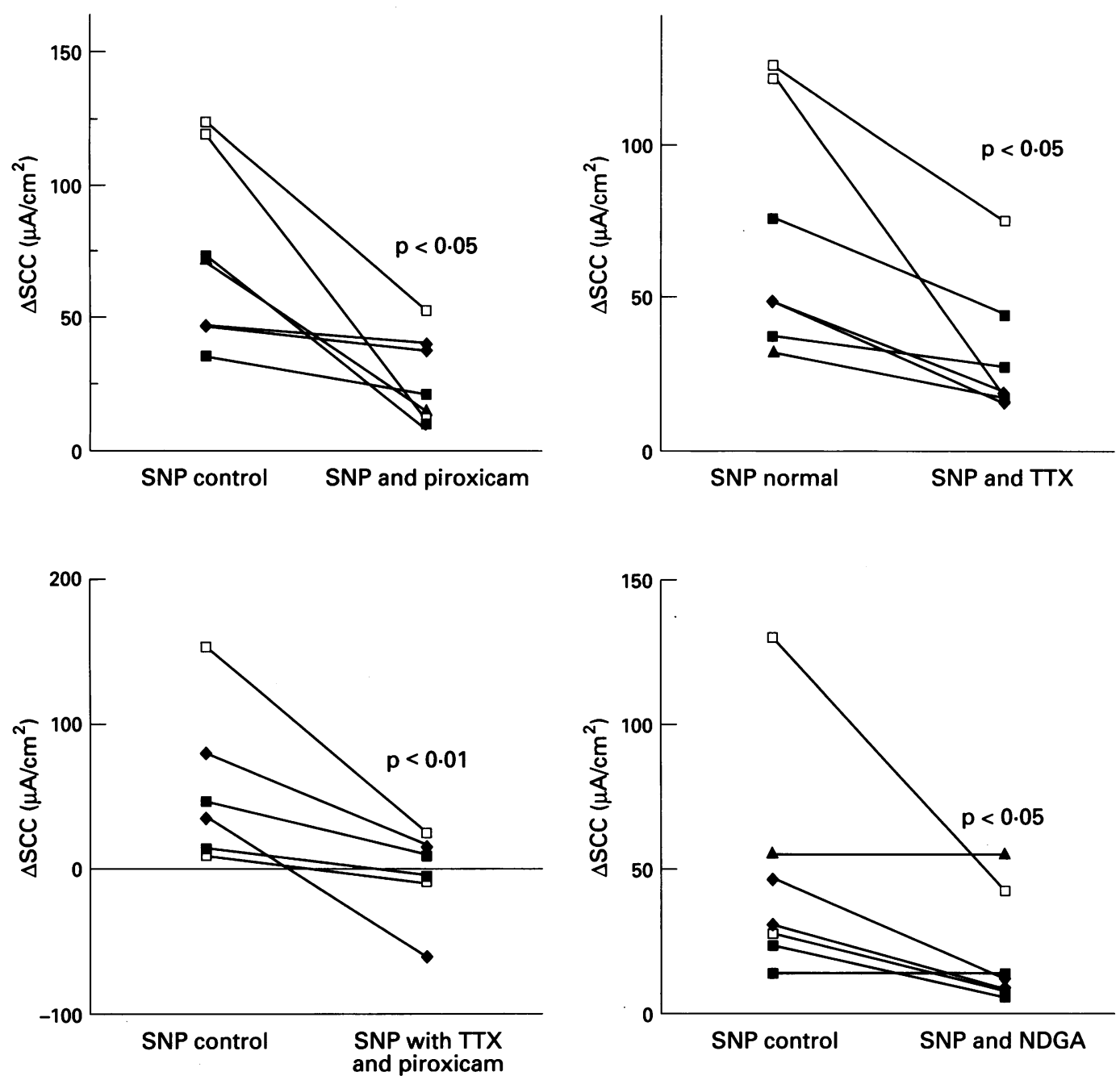

Figure 4: Investigation of possible mechanisms responsible for $\triangle S C C$ changes with $S N P$. $S N P\left(10^{-4} \mathrm{M}\right)$ was added basolaterally 15 minutes after basolateral piroxicam $\left(10^{-5} \mathrm{M}\right), \operatorname{TTX}\left(10^{-6} \mathrm{M}\right), \operatorname{TTX}\left(10^{-6} \mathrm{M}\right)$ and piroxicam $\left(10^{-5} \mathrm{M}\right)$ together, and NDGA $\left(10^{-4} \mathrm{M}\right)$. Piroxicam, TTX, and NDGA all significantly reduced $\triangle S C C$ response compared with basolateral $S N P\left(10^{-4} M\right)$ alone. The combination of TTX and piroxicam together practically abolished the response to SNP.

compounds we have shown that these can also stimulate human colonic ion transport.

Both SNP and SNAP have widely been used as NO donating compounds. ${ }^{9-11}$ SNP is a potent vasodilator used in clinical practice and causes vascular relaxation by releasing NO, which acts on guanylate cyclase. ${ }^{28}$ The mechanism by which SNP releases NO is not fully understood but it is thought to occur both spontaneously, ${ }^{29}$ and after contact with biological tissues. ${ }^{30-32}$ SNP has also been recently shown to cause increased cyclic-GMP production in isolated human colonic mucosa, ${ }^{33}$ which may account for its secretory action. Although most of the biological activity of SNP is thought to be due to NO, it may also have activity independent of NO, which can inhibit mucosal electrolyte transport. ${ }^{34}$ Therefore SNAP, a nitrosothiol that is structurally unrelated to SNP but which also releases NO, ${ }^{35}$ was used as an alternative NO donor. In human colon both SNP and SNAP gave a qualitatively similar increased $\triangle$ SCC (Fig 2). As repeated basolateral administration of SNP caused tachyphylaxis, a concentration response curve was constructed using separate tissues. The fact that repeated administration of SNP did not effect the subsequent $\Delta$ SCC response to carbachol shows that SNP induced tachyphylaxis is a real phenomenon rather than a decreased sensitivity due to a toxic affect. The $\mathrm{ED}_{50}$ for SNP in human colon is $2.5 \times 10^{-5} \mathrm{M}$, which is of the same order of magnitude as for rat colon $8 \times 10^{-5} \mathrm{M}^{10}$

Basal short circuit current in human colon was significantly reduced by apical amiloride indicating that basal ion transport was at least in part accounted for by sodium absorption. Previous studies have shown both basal electrogenic sodium absorption and electroneutral $\mathrm{Na}-\mathrm{Cl}$ co-transport in human colon in vitro. ${ }^{2636}$ In this study basal short circuit current was also significantly reduced by piroxicam, NDGA, and tetrodotoxin indicating that continuous synthesis of prostaglandins as well as local enteric nerves contribute to basal electrical tone, which has been previously demonstrated in human colon. ${ }^{21}$

The ionic basis of the increased $\triangle S C C$ in response to SNP was investigated both by using pharmacological inhibitors of known ion transporting processes and by ion replacement studies. We have concluded from these studies that electrogenic chloride secretion is the main contributor to the increased $\triangle \mathrm{SCC}$ as bumetanide and chloride free media inhibited 
$\Delta \mathrm{SCC}$ by $53 \%$ and $68 \%$ respectively. However, there may also be a contribution from bicarbonate secretion as the combination of SITS and bumetanide reduced $\triangle$ SCC greater than bumetanide alone although SITS alone did not significantly reduce $\triangle S C C$ to SNP. Amiloride at a concentration known to inhibit electrogenic sodium absorption in human colon ${ }^{26}$ had no effect on SNP induced $\triangle$ SCC increase indicating that electrogenic sodium absorption does not contribute to SNP induced increased $\Delta S C C$. These data are in keeping with the effect of SNP on experimental animal intestine. Bumetanide has been shown to attenuate the effect of SNP in rat $^{910}$ and guinea pig intestine $^{10}$ in vitro. In addition, ion flux studies in voltage clamped rat colon have demonstrated increased electrogenic chloride secretion and reduced mucosal to serosal sodium and chloride flux with a residual flux thought to be due to bicarbonate secretion. ${ }^{10}$ Our studies suggest that SNP evokes similar ion transporting events in human colon.

The mean $\triangle S C C$ response to SNP was greater when administered to the basolateral side of the preparation compared with apical side in paired tissues. To investigate possible mechanisms further, we used specific inhibitors of eicosanoid synthesis and neuronal transport applied basolaterally prior to the addition of SNP. Tetrodotoxin, an inhibitor of nerve function, and piroxicam and NDGA inhibitors of local prostanoid synthesis, significantly attenuated $\triangle S C C$ to SNP, while both tetrodotoxin and piroxicam together virtually abolished it. This suggests that the secretory response to NO requires enteric nerve function and local prostanoid synthesis for SNP induced changes in human colonic ion transport. Other Ussing chamber studies on secretagogue stimulated human colonic ion transport with activated mast cells and phagocytes have also shown that ion transport changes seem to be transduced through nerves and local eicosanoid synthesis. ${ }^{37} 38$

In summary, these studies show that NO donating compounds stimulate human colonic ion transport. For SNP this increased $\triangle S C C$ is for the most part due to electrogenic chloride secretion and possibly bicarbonate secretion and occurs through local prostanoid synthesis and via stimulation of enteric nerves. As macrophages, mast cells, and phagocytes have all been shown to have increased iNOS activity when activated in vitro, ${ }^{18-20}$ and as inflamed bowel contains a much greater quantity of a range of activated immunocytes, increased production of NO could be a possible mediator of diarrhoea in active inflammatory bowel disease through the stimulation of enteric nerves and by local eicosanoid synthesis.

We are grateful to the surgeons, and particularly Ms Kate Bostock in the Department of Surgery, University Hospital, Nottingham for their help in obtaining surgical specimens used in this study.

1 Furchgott RF, Zawadzki JV. The obligitory role of endothelial cells in the relaxation of arterial smooth muscle by acetyl choline. Nature 1980; 288: 373-6.

2 Moncada S, Palmar RMJ, Higgs EA. Nitric oxide: physiology, pathophysiology and pharmacology. Pharmacol Rev 1991; 43: 109-42.
3 Moncada S, Higgs EA. The L-arginine nitric oxide pathway. $N$ Engl f Med 1993; 329: 2002-12.

4 Stark ME, Szurszewski JH. Role of nitric oxide in gastrointestinal and hepatic function and disease. Gastroenterology 1992; 103: 1928-49.

5 Bult H, Boeckxstaens GE, Pelckmans CA, Jordaens FH, Van Maerke YM. Nitric oxide as a non-adrenergicnon-cholinergic neurotransmitter. Nature 1990; 345: non-cholir 7 .

6 Hata F, Ishii T, Kanada A, Yamano N, Kataoka T, Takeuchi $T$, et al. Essential role of nitric oxide in descending inhibition in the rat proximal colon. Biochem Biophys ing inhibition in the rat proximal

7 Mourelle M, Guarner F, Moncada S, Managelada JR. The arginine/nitric oxide pathway modulates sphincter of Oddi motor activity in guinea pigs and rabbits. Gastroenterology 1993; 105: 1299-305.

8 Kubes P. Nitric oxide modulates epithelial permeability in the feline small intestine. Am $f$ Physiol 1992; 262: G1138-42.

9 Tamai H, Gaginella TS. Direct evidence for electrolyte secretion in the rat colon. Free Radic Res Commun 1993; 19: 229-39.

10 Wilson KT, Yue X, Musch MW, Chang EB. Sodium nitroprusside stimulates anion secretion and inhibits sodium chloride absorption in the rat colon. $\mathcal{f}$ Pharmacol Exp Ther 1993; 266: 224-30.

11 McNaughton WK. Nitric oxide-donating compounds stimulate electrolyte transport in the Guinea pig intestine in vitro. Life Sci 1994; 53: 585-93.

12 Field M, Rao M, Chang EB. Intestinal electrolyte transport and diarrhoeal disease (part 2). N Engl f Med 1989; 321: 879-83.

13 Mascolo N, Izzo AA, Autore G, Barbato F, Capasso F. Nitric oxide and castor oil induced diarrhoea. $\mathcal{F}$ Pharmacol Exp Ther 1994; 268: 291-5.

14 Gaginella TS, Mascolo N, Izzo AA, Autore G, Capasso F. Nitric oxide as a mediator of bisacodyl and phenolphthalein laxative action: induction of nitric oxide synthase. $\mathcal{F}$ Pharmacol Exp Ther 1994; 270: 1239-45.

15 Boughton-Smith NK, Evans SM, Whittle BJR, Moncada S. Intestinal damage and the induction of nitric oxide synthase in the rat. Br F Pharmacol 1992; 107: 79P.

16 Boughton-Smith NK, Evans SM, Hawkey CJ, Cole AT, Whittle BJR, Moncada S. Nitric oxide synthase activity in ulcerative colitis and Crohns disease. Lancet 1993; 342: 338-40.

17 Middleton SJ, Shorthouse M, Hunter JO. Increased nitric oxide synthesis in ulcerative colitis. Lancet 1993; 341: 465-6.

18 Bissonette EY, Hoagboam CW, Wallace JL, Befus AD. Potentiation of tumour necrosis factor mediated cytotoxicity of mast cells by their production of nitric oxide. city of mast cells by their prod

19 McCall TB, Boughton Smith NK, Palmar RNJ, Whittle BJR, Moncada S. Synthesis of nitric oxide from LArginine by neutrophils. Release and interaction with superoxide anion. Biochem $\mathcal{f} 1989 ; 261: 293-6$.

20 Hibbs JB, Taintor RR, Vavrin Z, Rachlin EM. Nitric oxide; a cytotoxic activated macrophage effector molecule. Biochem Biophys Res Commun 1988; 157: 87-94.

21 Keely SJ, Stack WA, O'Donoghue D, Baird AW. Regulation of ion transport by histamine in the human colon. Eur $\mathcal{F}$ Pharmacol 1995; 279: 203-9.

22 Riegler M, Sedivy R, Pothoulakis C, Hamilton G, Zacherl J, Bischof $\mathrm{G}$, et al. Clostridium difficile toxin $\mathrm{B}$ is more Bischof $\mathrm{G}$, et al. Clostridium difficile toxin $\mathrm{B}$ is more potent than toxin A in damaging human

23 O'Grady SM, Palfrea HC, Field M. Characteristics and functions of Na-K-Cl cotransport in epithelial tissues. $A m$ f Physiol 1978; 105: 764-72.

24 Feldman GM. HCO3 secretion by rat distal colon: Effects of inhibitors and extra cellular sodium. Gastroenterology 1994; 107: 329-39.

25 Lopes AG, Siebens AW, Giebisch G, Boran WF. Electrogenic $\mathrm{Na} / \mathrm{HCO} 3$ cotransport across basolateral membrane of isolated perfused Nectarus proximal tubule. Am f Physiol 1987; 253: F340-50.

26 Rask-Madsen J, Hjelt K. Effect of amiloride on electrical activity and sodium transport in human colon. Scand $\mathcal{f}$ activity and sodium transport

27 Kuwahara A, Cooke HJ, Carey HV, Mekhjian H, Ellison EC, McGregor B. Effects of enteric neural stimulation on chloride transport in human distal colon in vitro. Dig Dis Sci 1989; 34: 206-13.

28 Arnold WP, Mittal CK, Katsuki S, Murad F. Nitric oxide activates guanylate cyclase and increases guanosine $3^{\prime}: 5^{\prime}-$ cyclic monophasphate levels in various tissue preparations. Proc Natl Acad Sci USA 1977; 74: 3203-7.

29 Frank MJ, Johnson JB, Rubin SH. Spectro-photometric determination of sodium nitroprusside and it's degradation products. $\mathcal{F}$ Pharm Sci 1976; 65: 44-8.

30 Bates JN, Baker MT, Guerra R, Harrison DG. Nitric oxide generation from nitroprusside by vascular tissue. Biochem Pharmacol 1991; 42: S157-62.

31 Ignarro LJ, Edwards JC, Gruetter DY, Barry BK, Gruetter C. Possible involvement of S-nitrosothiols in the activaC. Possible involvement of S-nitrosothiols in the activa-
tion of guanylate cyclase by nitroso compounds. FEBS tion of guanylate cyclase

32 Freelisch $M$, Noacke E. Nitric oxide formation from nitrovasodilators occurs independently of haemoglobin and non-haem iron. Eur $\mathcal{f}$ Pharmacol 1987; 142: 467-9.

33 Kuhn $M$, Adermann K, Jahne J, Forssmann WG, Rechkemmer G. Segmental differences in the effects of 
guanylin and Escherichia coli heat-stable enterotoxin on chloride secretion in human gut. F Physiol 1994; 479.3: 433-40.

34 Stutts MJ, Gatzy T, Boucher RC. Effects of metabolic inhibition on ion transport by dog bronchial epithelium. inhibition on ion transport by dog bronchial epithelium.

35 Ignarro LJ, Lippton H, Edwards JC, Baricos WH, Hyman AL, Kadowitz PJ, et al. Mechanisms of vascular smooth muscle relaxation by organic nitrates, nitrites, nitroprusside and nitric oxide; evidence for the involvement of S-nitrosothiols as active intermediates. $f$ Pharmacol Exp Ther 1981; 218: 739-49.

36 Sellin JH, De Soigne R. Ion transport in the human colon in vitro. Gastroenterology 1987; 93: 441-8.

37 Stack WA, Keely SJ, O'Donoghue DP, Baird AW. Immune regulation of human colonic ion transport in vitro. Gut 1995; 36: 395-400

38 Crowe SE, Perdue $M$ H. Anti-IgE stimulated ion transport in human small and large intestine. Gastroenterology 1993; 105: 764-72. 